\title{
Cognitive and functional ability of elderly women practitioners of different modalities of exercise
}

\author{
Capacidade funcional e cognitiva de idosas praticantes de diferentes modalidades de \\ exercícios físicos
}

\author{
Capacidad funcional y cognitiva de ancianos practicantes de diferentes modalidades de \\ ejercicios físicos
}

Daniel Vicentini de Oliveira ${ }^{1}$, Ana Paula Serra Araújo ${ }^{2}$, Sônia Maria Marques Gomes Bertolini ${ }^{3}$

Objective: to compare the functional capacity and cognitive ability of elderly women engaged in various forms of physical exercise. Methods: quantitative, cross-sectional, descriptive, observational and analytical study with 120 volunteers, divided into three groups of 40 elderly: water aerobics group, fitness center of the third age group and weight training group. Functional ability was assessed by functional evaluation Protocol of the Latin American Development Group for the Maturity and the cognitive ability was assessed using the Mini-Mental State Examination. Results: the functional capacity of elderly in the three modalities were classified as weak, showing no significant difference between groups $(p=0.082)$. Cognitive ability reached nearly maximum scores in the three modalities of exercise, without statistical significance $(p=0.062)$. Conclusion: functional capacity of elderly women is low and the type of exercise does not interfere with cognitive performance.

Descriptors: Aged; Motor Activity; Aging; Health Promotion.

Objetivo: comparar a capacidade funcional e cognitiva de idosas praticantes de diferentes modalidades de exercício físico. Métodos: estudo quantitativo, transversal, descritivo, observacional e analítico, com 120 voluntárias, divididas em três grupos de 40 idosas: grupo hidroginástica, grupo academia da terceira idade e grupo musculação. A capacidade funcional foi avaliada por meio do Protocolo de avaliação funcional do Grupo de Desenvolvimento Latino Americano para a Maturidade e para a avaliação cognitiva foi usado Mini Exame do Estado Mental. Resultados: a capacidade funcional das idosas nas três modalidades foi classificada como fraca, não apresentando diferença significante entre os grupos $(p=0,082)$. A capacidade cognitiva apresentou escores próximos à pontuação máxima nas três modalidades de exercício, sem significância estatística $(\mathrm{p}=0,062)$. Conclusão: é baixa a capacidade funcional das idosas avaliadas bem como o tipo de exercício físico não interfere no desempenho cognitivo.

Descritores: Idoso; Atividade Motora; Envelhecimento; Promoção da Saúde.

Objetivo: comparar la capacidad funcional y cognitiva de ancianas practicantes de diversas modalidades de ejercicio físico. Métodos: estudio cuantitativo, transversal, descriptivo, de observación y analítico, con 120 voluntarios, divididos en tres grupos de 40 ancianas: aeróbic, Academia de la Tercera Edad y grupo musculación. La capacidad funcional se evaluó mediante evaluación funcional del Protocolo Grupo de Desarrollo de América Latina para madurez, y la evaluación cognitiva se utilizó Mini-Mental del Estado Mental. Resultados: la capacidad funcional de las ancianas en las tres modalidades se clasificaron como débil, mostrando diferencias significativas entre los grupos $(\mathrm{p}=0,082)$. La capacidad cognitiva mostró puntajes cerca de puntuación perfecta en las tres modalidades de ejercicio, sin significación estadística ( $p=0,062)$. Conclusión: es baja la capacidad funcional de las ancianas evaluadas, así como el tipo de ejercicio no interfiere en el rendimiento cognitivo.

Descriptores: Anciano; Actividad Motora; Envejecimiento; Promoción de la Salud.

\footnotetext{
${ }^{1}$ União das Faculdades Metropolitanas de Maringá. Maringá, PR, Brazil.

${ }^{2}$ Faculdade Guairacá. Guarapuava, PR, Brazil.

${ }^{3}$ Centro Universitário Cesumar. Maringá, PR, Brazil.
} 


\section{Introduction}

The aging process varies greatly between individuals and is influenced by lifestyle and genetic factors. In this process, functional capacity proves to be one of the most relevant concepts in relation to health, fitness and quality of life $\mathrm{e}^{(1)}$.

Regular physical exercise has been adopted as an auxiliary strategy for reducing the impact of aging on functional capacity and quality of life. It is common to associate the functional autonomy to impairments that trigger physical dependence, cognitive and psychic impairment ${ }^{(2)}$.

Cognitive ability is also one of the key factors for quality of life in old age, since losses of cognitive function may result in impaired physical, social and emotional functioning of the elderly. There is evidence that cognitive impairment is strongly associated with the mobility impairment as well as spatial disorientation and deterioration of the executive functions. Physical activity can improve mental health and contribute to prevention of disorders such as depression and dementia ${ }^{(3)}$.

Exercise is a health-promoting factor essential for active aging ${ }^{(4-5)}$. For any individual, the type, intensity and frequency of exercise are important factors for induction of morphological and physiological changes ${ }^{(6)}$. In this sense, different types of exercise have been proposed for elderly, including water aerobics, dance, weight training, generalized gymnastics and walking. Considering the existing activities, the American College of Sports Medicine points out that walking is the most common and weight training is the most recommended to retard sarcopenia $^{(7)}$.

The decline in functional capacity in recent years has resulted in increased demand for physical exercise in aquatic medium ${ }^{(8)}$. This increase is mainly related to the physical properties of water, its cardiorespiratory benefits allies and the fact that water reduces joint damage when compared to exercises out of the water ${ }^{(9)}$.
Water aerobics have been also used as a form of therapy for various diseases and disorders such as osteoarthritis, inflammation, osteoporosis, among others ${ }^{(10)}$. Orthopedic stress is reduced in the water and this makes this form of exercise especially favorable for individuals who are at high risk of fractures related to $\operatorname{impact}^{(10)}$.

Resistance exercise has been considered a promising intervention to prevent or reverse, at least partially, the loss associated with aging. Weight training has been strongly recommended for old age, for improving functional abilities, health status, quality of life and independence of the elderly ${ }^{(11)}$.

Prejudice against exercises with weight associated with lack of knowledge of its correct application, hindered for many years the benefits that this modality of exercise could offer, especially to elderly.

In order to provide better quality of life for the elderly of the city of Maringa in the northwestern side of the Paraná state, the Municipal Department of Health took the initiative to create Fitness Centers for the Third Age. These centers have ten metallic training machines recovered by rubber, free of weights, biomechanically designed for physical activity.

Given the above, we formulated the following research question: do the different forms of exercise practiced by the elderly have the same impact on functional and cognitive ability?

Thus, the aim of this study was to compare the functional capacity and cognitive ability of elderly women engaged in various forms of physical exercise.

\section{Method}

This is a quantitative, cross-sectional, descriptive, observational and analytical study. Were included in the study elderly women at least 60 years old and at most 70 years old that practice water aerobics, exercise in fitness centers for old age and weight training for at least three months and with a frequency of twice a week. Elderly women who had 
neurological disorders (with motor and psychical signs and symptoms) were excluded because these would impede tests. The exclusion of male participants and elderly over 70 years in the study is justified by the fact that the elderly of that sex and elderly over 70 years mostly do not practice activities in the fitness centers for the third age.

The modalities of exercise mentioned above were selected because they are considerably predominant in the preference of older practitioners when compared to other exercises such as dance, Pilates, gymnastics in the gym, among others.

The study was conducted with 120 volunteers divided into three groups of 40 elderly women: Water aerobics Group, Fitness Center for the Third Age Group and Weigh Training Group. A semistructured form was used to characterize the sample consisting of information regarding age, marital status, employment status, monthly income in terms of minimum wage referenced by the Demographic Population Census 2010 of the Brazilian Institute of Geography and Statistics ${ }^{(12)}$, modality of physical exercise, weekly frequency and the total time of practicing that modality of exercise.

Tests determined in the Functional Assessment Protocol of the Latin American Development Group for Maturity (LADGM) were used: walk 10 meters (W10m), stand up from a seated position (SSP), stand up from the position of ventral decubitus (SPVD), stand up from the chair and move around the house (SCMA), and dress and undress a shirt (DUS) ${ }^{(1)}$.

All tests were used to calculate the Index of the Functional Assessment Protocol of Latin American Development Group for Maturity and time was calculated in seconds. Smaller scores represent higher level of functional autonomy. The Functional Assessment Protocol of the Latin American Development Group for Maturity was calculated as follows:

$\underline{\mathrm{LADGM}}=[\mathrm{W} 10 \mathrm{~m}+\mathrm{SSP}+\mathrm{SPVD}+\mathrm{DUS} \times 2]+\mathrm{SCMA}$ 4
Each test also received a rating that ranges from poor, fair, good or very good. The Table 1 shows these patterns of the instrument Functional Assessment Protocol of the Latin American Development Group to Maturity ${ }^{(1)}$ serving as the reference for analysis of the classification of surveyed indexes.

Table 1 - Evaluation Standards of the functional capacity of the Functional Assessment Protocol of the Latin American Development Group for Maturity ${ }^{(1)}$

\begin{tabular}{|c|c|c|c|c|}
\hline \multirow[b]{2}{*}{ Tests } & \multicolumn{4}{|c|}{ Classification } \\
\hline & Poor & Fair & Good & $\begin{array}{l}\text { Very } \\
\text { good }\end{array}$ \\
\hline Walk 10 meters $^{1}$ & +7.09 & $7.09-6.34$ & $6.33-5.71$ & -5.71 \\
\hline Stand up from a seated position ${ }^{1}$ & +11.19 & $11.19-9.55$ & $9.54-7.89$ & -7.89 \\
\hline $\begin{array}{l}\text { Stand up from the position of } \\
\text { ventral decubitus }{ }^{1}\end{array}$ & +4.40 & $4.40-3.30$ & $3.29-2.63$ & -2.63 \\
\hline $\begin{array}{l}\text { Stand up from the chair and move } \\
\text { around the house } \mathrm{e}^{1}\end{array}$ & +43.00 & $43.29-38.69$ & $38.68-34.78$ & -34.78 \\
\hline Dress and undress a shirt ${ }^{1}$ & +13.14 & $13.14-11.62$ & $11.61-10.14$ & -10.14 \\
\hline $\begin{array}{l}\text { Functional Assessment Protocol of } \\
\text { the Latin American Development } \\
\text { Group for Maturity }^{2}\end{array}$ & +27.42 & $27.42-24.98$ & $24.97-22.26-$ & -22.26 \\
\hline
\end{tabular}

The Mini-Mental State Examination was used for cognitive evaluation ${ }^{(13)}$. This test consists of questions grouped into seven categories: temporal orientation, spatial orientation, registration of three words, attention and calculation, recall of three words, language and constructive vision capability and varies according to the level of education: illiterate (cut-off score 20), from one to four years of schooling (cutoff 25 ), five to eight years of schooling (cutoff 26.5), nine to 11 years of schooling (cutoff 28) and over 11 years of schooling (cutoff 29).

Data collection was performed by the researcher and a team of professional collaborators in 18 fitness centers. Thirteen centers offered the modalities of water aerobics and/or weight training, registered in Sector Nucleus of Fitness Centers and Swim Schools and five Fitness Centers for the Third Age (Parque do Ingá, Vila Olímpica, Parque das Grevilhas, Bosque II and Parigot de Souza) in the period of April to August 
2013. Collection was held before the scheduled execution of exercises to avoid potential interference in the expressed information.

Statistical analysis was performed using the software Statistical Package for Social Sciences version 17.0. Normality was tested with Shapiro-Wilk test and means were compared through One-Way Analysis of Variance followed by Turkey post-hoc test when normality in each group to compare and homogeneity of variance. We performed the Kruskal Wallis test when variances were different, that is, heterogeneous, and normality was sought in at least one of the groups under comparison, Fisher test and chi-square. For all tests, a significance level of $\mathrm{p}<0.05$ was adopted.

Participant elderly were informed about the justification, goals and procedures to be performed as guidelines for research with human beings contained in Resolution 196/96 of the National Health Council, after signing the Informed Consent. The study was approved by the Ethics Committee on Research Involving Human Beings of Cesumar University Center through the report no $217.895 / 2012$.

\section{Results}

Similarity between groups regarding mean age of the Water Aerobics group (65.5 \pm 3.7$)$, Fitness Center for the Third Age Group (65.6 \pm 4.8$)$ and Weigh Training group $(63.9 \pm 5.8)$ shows careful application of inclusion and exclusion criteria eliminating the interference of this feature on the results.

Main features of the three study groups (water Aerobics Group, Fitness Center for the Third Age Group and Weigh Training group) are presented in Table 2.
Table 2 - Profile Characterization of elderly groups according to Water Aerobics group, Fitness Center for the Third Age Group and Weigh Training group

\begin{tabular}{|c|c|c|c|c|}
\hline \multirow[b]{2}{*}{ Variables } & \multicolumn{3}{|c|}{ Groups } & \multirow[b]{2}{*}{ P value* } \\
\hline & $\begin{array}{c}\text { Water } \\
\text { aerobics } \\
\text { n(\%) }\end{array}$ & $\begin{array}{l}\text { Fitness center } \\
\text { for the third } \\
\text { age } n(\%)\end{array}$ & $\begin{array}{c}\text { Weigh } \\
\text { training } \\
\mathbf{n}(\%)\end{array}$ & \\
\hline \multicolumn{5}{|l|}{ Age (years) } \\
\hline $60-65$ & $15(37.5)$ & $23(57.5)$ & $24(60.0)$ & $0.087(Q)$ \\
\hline $66-70$ & $25(62.5)$ & $17(42.5)$ & $16(40.0)$ & \\
\hline \multicolumn{5}{|l|}{ Marital status } \\
\hline Married & $19(47.5)$ & $22(55.0)$ & $19(47.5)$ & $0.740(\mathrm{Q})$ \\
\hline Not married & $21(52.5)$ & $18(45.0)$ & $21(52.5)$ & \\
\hline \multicolumn{5}{|c|}{ Occupational status } \\
\hline Active & $25(62.5)$ & $18(45.0)$ & $22(55.0)$ & \\
\hline Inactive & $15(37.5)$ & $22(55.0)$ & $18(45.0)$ & $0.288(F)$ \\
\hline \multicolumn{5}{|c|}{ Schooling (years) } \\
\hline $1-4$ & $8(20.0)$ & $18(45.0)$ & $4(10.0)$ & \\
\hline $5-8$ & $12(30.0)$ & $12(30.0)$ & $8(20.0)$ & $<0.001^{*}(\mathrm{~F})$ \\
\hline$>8$ & $20(50.0)$ & $10(25.0)$ & $28(70.0)$ & \\
\hline \multicolumn{5}{|c|}{$\begin{array}{l}\text { Monthly income } \\
\text { (minimun wages) }\end{array}$} \\
\hline$\geq 1$ & $1(2.5)$ & $2(5.0)$ & $3(7.5)$ & \\
\hline $1-2$ & $9(22.5)$ & $23(57.5)$ & $4(10.0)$ & $<0.001^{*}(\mathrm{~F})$ \\
\hline$>2$ & $30(75.0)$ & $15(37.5)$ & $33(82.5)$ & \\
\hline \multicolumn{5}{|c|}{ Time of practice (years) } \\
\hline$<1$ & $2(5.0)$ & $5(12.5)$ & $13(32.5)$ & \\
\hline $1-5$ & $22(55.0)$ & $30(75.0)$ & $23(57.5)$ & $<0.001^{*}(\mathrm{~F})$ \\
\hline $6-10$ & $9(22.5)$ & $5(12.5)$ & $1(2.5)$ & \\
\hline$>10$ & $7(17.5)$ & - & $3(7.5)$ & \\
\hline \multicolumn{5}{|c|}{ Weekly frequency } \\
\hline 2 & $26(65.0)$ & $4(10.0)$ & $3(7.5)$ & \\
\hline 3 & $12(30.0)$ & $15(37.5)$ & $20(50.0)$ & $<0.001^{*}(\mathrm{~F})$ \\
\hline 4 & $2(5.0)$ & $21(52.5)$ & $17(42.5)$ & \\
\hline
\end{tabular}


There was no statistically significant difference in between any modality practiced by the elderly in terms of age, marital status and occupational status. As for education, there was predominance of elderly women with more than eight years of schooling and monthly income above two minimum salaries in water aerobics group and weigh training Group.

One to five years of practice time was reported by most of the elderly of the three groups. Regarding weekly frequency, lower frequency was found in Water Aerobics Group (twice a week), followed by Weigh Training Group (three times weekly) and Fitness Center for the Third Age Group (four or more times a week ).

Scores of the test 'walk 10 meters' and 'stand up from the position of ventral decubitus' of the three groups were all classified as weak. Elderly practitioners of physical exercises at Fitness Centers for the Third Age had better scores on the test 'stand up from the chair and move around the house' $(<0.001)$ and weigh training practitioners showed better results in the test 'stand up from the ventral decubitus position' ( $p$ $=0.001$ ).
In the test of Dress and undress a shirt, the worst findings ( $p<0.001$ ) were observed in the Fitness Center for the Third Age Group (Table 3).

The general index of functional capacity of elderly practitioners of different modalities of exercise was classified as poor with no statistically significant difference between groups ( $\mathrm{p}=0.082)$, but the Group weigh training got better scores (Table 3 ).

The assessment of cognitive abilities of the groups using the Mini-Mental State Examination showed nearly perfect scores (30 points) in the three groups and the mean was not statistically different between groups (Table 4).

Table 4 - Average scores on the Mini-Mental State Examination in groups practitioners of physical exercise

\begin{tabular}{lllll}
\hline Variable & Grupo (n=40) & Mean & $\begin{array}{l}\text { Standard } \\
\text { deviation }\end{array}$ & P-value* \\
\hline & $\begin{array}{l}\text { Water Aerobics } \\
\text { Group }\end{array}$ & 27.3 & 3.0 & \\
& & & & \\
$\begin{array}{l}\text { Mini-Mental State } \\
\text { Examination }\end{array}$ & $\begin{array}{l}\text { Fitness Centers for } \\
\text { Third Age Group }\end{array}$ & 27.3 & 2.9 & 0.062 \\
& Weigh Training & 27.8 & 2.9 & \\
& *Shapiro-Wilk test; One-Way ANOVA; post-hoc Tukey test
\end{tabular}

Table 3 - Values of tests for functional capacity of the functional evaluation Protocol of the Latin American Development Group for Maturity of the groups of elderly practitioners of exercise (Water Aerobics Group; Fitness Centers for Third Age Group and Weigh Training Group)

\begin{tabular}{|c|c|c|c|c|}
\hline \multirow[b]{2}{*}{ Tests } & \multicolumn{3}{|c|}{ Groups } & \multirow[b]{2}{*}{ P-value } \\
\hline & Water aerobics & $\begin{array}{l}\text { Fitness centers for } \\
\text { third age }\end{array}$ & $\begin{array}{l}\text { Weigh } \\
\text { Training }\end{array}$ & \\
\hline Walk 10 meters (seconds) & $10.7 \pm 3.3$ Poor & $10.8 \pm 5.9$ Poor & $9.8 \pm 2.9$ Poor & 0.159 \\
\hline Stand up from the chair and move around the house (seconds) & $45.8 \pm 9.5$ Poor & $29.2 \pm 8.8$ Very good & $37.7 \pm 8.0$ Fair & $<0.001^{*}(\mathrm{~A})$ \\
\hline Stand up from the position of ventral decubitus (seconds) & $9.8 \pm 4.5$ Poor & $11.4 \pm 8.7$ Poor & $6.8 \pm 2.9$ Poor & $<0.001^{*}(\mathrm{~B})$ \\
\hline Stand up from a sitting position (seconds) & $10.4 \pm 4.2$ Fair & 10.4 \pm 4.9 Fair & $11.5 \pm 4.0$ Poor & $0.023^{*}(\mathrm{C})$ \\
\hline Stand up from the position of ventral decubitus (seconds) & $9.1 \pm 2.9$ Very good & $14.6 \pm 7.3$ Poor & $10.7 \pm 3.6$ Good & $<0.001^{*}(\mathrm{D})$ \\
\hline $\begin{array}{l}\text { Functional evaluation Protocol of the Latin American Development } \\
\text { Group for Maturity (scores) }\end{array}$ & $31.5 \pm 5.6$ Poor & $31.8 \pm 12.2$ Poor & $28.7 \pm 5.3$ Poor & 0.082 \\
\hline
\end{tabular}




\section{Discussion}

The finding that older males mostly do not practice aerobics and weight training justify their exclusion as participants. Another reason for higher percentage of elderly women in physical exercise programs can be explained by the fact that they live about seven years longer than men ${ }^{(3)}$.

The number of married and unmarried elderly women ( $p=0.740)$ as well as occupationally active and inactive $(\mathrm{p}=0.288)$ proved to be very homogeneous in both groups, with no statistically significant difference.

The highest concentration of elderly women with more than eight years of schooling was found in the water aerobics group and Weigh Training Group. Among elderly women in the Fitness Center for the Third Age Group, most had one to four years of schooling. With respect to monthly income, most elderly of Water Aerobics Group and Weigh Training Group received more than two minimum wages, and elderly women at the Fitness Center for the Third Age group had one to two minimum salaries. Elderly need to invest a monthly cost in order to practice water aerobics or weight training, what does not happen at the Fitness Center for the Third Age group. It is known that there is an association between education and economic class of the individual.

The time of practice reported by most of elderly in the three modalities was one to five years, although weight training has been considered a recent form of fitness for seniors while water aerobics is considered the oldest mode and longer indicated for this population ${ }^{(5)}$.

The functional evaluation Protocol of the Latin American Development Group for the Maturity, which is used to assess functional capacity, resembles the assessment of activities of daily living and is being widely used for the elderly ${ }^{(1)}$. Functional capacity was classified as weak in all forms of physical exercise. Although weigh training has shown the best results, these were not statistically significant. Although the majority of elderly are practicing physical exercises with predominance of one to five years of practice, this classification points to the need to step up so much time, as the intensity of these activities.

Through the functional evaluation Protocol of the Latin American Development Group for the Maturity, different studies have analyzed the functional capacity of elderly. One evaluated elderly between 60 and 77 years post intervention with a resistance training program, getting a functional evaluation Protocol of the Latin American Development Group for the Maturity for classified as good, that is, an even better score than older practitioners of weight training in the present study (functional evaluation Protocol of the Latin American Development Group for the Maturity weak) ${ }^{(14)}$. Another study conducted intervention with exercise in elderly women with a mean age of 64.5 years, confirming a regular functional capacity $^{(15)}$.

Good ratings in the test to walk 10 meters are considered satisfactory for an elderly, indicating that he/she may cross a street safely ${ }^{(1)}$. With regard to that test, one can see that elderly practitioners of the three exercise modalities had poor functional capacity but there was no significant statistic difference between groups. The better classification of the elderly of the Weight Training group in the test to walk 10 meters can be explained by the fact that performing these exercises strengthens major muscle groups such as quadriceps and buttock tibial beyond the flexor muscles of the hip, responsible for the march. There is no hard work for that muscle in water aerobics and the Fitness Center for the Third Age group compared to weight training. The Fitness Center for the Third Age group, for the exercises, we use the strength of the own body weight or equipment in most equipment.

The functional capacity of a training group for endurance and flexibility was investigated in 2005. Results of such study showed significant improvement in both groups in all tests of the Protocol of the Latin American Development Group for the Maturity, while the strength group had obtained more satisfactory results in 10 meters walk test ${ }^{(16)}$. 
The purpose of the test to get up from the chair and move around the house is to evaluate the ability of the elderly regarding agility and balance in daily life situations $^{(1)}$. In this test the result in the Group Fitness Center for the Third Age group was considered as very good (Fitness Center for the Third Age group was better than Weigh Training Group and Water Aerobics Group). These findings may be explained by the fact that these elderly perform, in addition to exercises with equipment in the fitness center, hiking in the physical spaces where they are installed.

In weight training, agility work and balance it is not the priority, but the strength and muscular endurance. In the water aerobics, the physical properties of water, such as thrust, cause the elderly to need less balance for carrying out activities.

Another test whose result was classified as weak, in all forms of exercise, was the test of getting up from the ventral decubitus position. It is worth noting that even before this classification, Weigh Training group showed better scores than the Fitness Center for the Third Age group. This fact, too, can be explained by the quality of the workforce held in Weigh Training, unlike other modalities. The act of getting up from the position of ventral decubitus and standing up requires an individual control and strength of the whole body muscles $^{(1)}$.

The test 'stand from a sitting position' evaluates the strength and endurance of the lower body segments ${ }^{(17)}$ and, in this study, Water Aerobics Group and Fitness Center for the Third Age group obtained equal results, classified as regular functional capacity. In Group Weigh Training, autonomy was classified as weak. The loss of muscle strength is evidenced in aging and the decrease is greater in the lower $\operatorname{limbs}^{(5)}$. In water aerobics, the legs are entirely submerged and consequently require overcoming water resistance so that the individual can move, which could lead to increased muscular strength and endurance of these elderly, helping in the task of standing up from a sitting position.

In the test dressing and undressing a shirt, the best results were found among the Water Aerobics Group, rated as very good, what can be justified by motor coordination and flexibility work carried out in water aerobics classes ${ }^{(9)}$.

Water aerobics is standing out and winning a growing number of fans, so much so that the popularity of aquatic exercises has increased significantly the last 10 years ${ }^{(18)}$. However, studies that aim to evaluate the functional capacity of elderly practitioners of this exercise modality are scarce.

As for weight training, similar to the present research, a recent study ${ }^{(14)}$ carried out in 2012 applied the test of dressing and undressing a shirt in elderly and found results that were classified as good.

Even with regard to the practice of strength and functional capacity, elderly underwent a 16-week resistance training and obtained significant results in gaining muscle strength and decreasing time in tests of walking 10 meters and standing up from a sitting position ${ }^{(16)}$. This was an experimental study developed during 140 days with a frequency of three times a week without interruption.

The aging process is accompanied not only by the decline of physical abilities, but also cognitive, which may vary according to each individual's life characteristics. Neuropsychological changes are noted as: cognitive deficits, changes in memory, reasoning, episodes of confusion and psychological disorders, which may be related to dementia and depressive symptoms $^{(19)}$.

The evidence regarding the association between exercise and dementia are still insufficient. It is observed the need for studies to investigate this association in both, seniors who already have a diagnosis of dementia and seniors with no previous diagnosis as well as investigations of more definitions regarding the type, duration and intensity of exercise.

The assessment of cognitive abilities held by the Mini Mental State Examination revealed no cognitive decline and the differences between means were not statistically significant indicating that in all groups cognitive ability was normal. With these results, we 
can infer that, regardless of physical exercise modality practiced in physically active elderly, cognitive ability tends to be preserved longer.

Physical exercise, especially when done in a group such as water aerobics, enables the elderly to express themselves and verbalize about their life experiences. It allows a space for exchange, host and strengthening of bond. as a group, and the elderly have the opportunity to socialize, get support, feel acknowledged in the pursuit and preservation of their autonomy and dignity ${ }^{(5)}$.

In addition, physical exercise seems to minimize the feeling of loneliness of elderly, even though many of them live with family. Advancing age is notably a determining factor for cognitive decline.

Despite important information produced, this study has some limitations that deserve to be highlighted, such as the lack of familiarity of the tests and of the control of usual physical activity of the participants, which could help in the interpretation of the differences found between groups.

\section{Conclusion}

The results show that there are no differences between functional and cognitive capacity of elderly practicing water aerobics, fitness center for the third age and weight training. Functional capacity of elderly, regardless physical exercise practiced, was considered weak, and cognitive ability was classified as normal, suggesting a positive impact of exercise on mental health of elderly.

The study has some limitations such as the lack of a control group made up of elderly nonpracticing physical exercise. Another aspect to be highlighted refers to the different locations of data collection, which may result in different measurements and classifications. However, even with the limitations mentioned, this research may provide important knowledge for health professionals about the importance of encouraging and intensifying the practice of physical exercises, as one of the determinants of promotion of the elderly Health.

\section{Colaborations}

Oliveira DV and Bertolini SMMG contributed to the design, collection of field data and analysis and interpretation of data and writing of the article. Araújo APS contributed to the design and final approval of the version to be published.

\section{References}

1. Guimarães AC, Rocha CAQC, Gomes ALM, Cader SA, Dantas EHM. Efeitos de um programa de atividade física sobre o nível de autonomia de idosos participantes do programa de saúde da família. Fit Perf J. 2008; 7(1):5-9.

2. Perez A J, Tavares O, Fusi FB, Daltio GL, Farinatti PTV. Estudo comparativo da autonomia de ação de idosas praticantes e não praticantes de exercícios físicos regulares. Rev Bras Med Esp. 2010; 16(4):254-8.

3. Beckert $\mathrm{M}$, Irigaray $\mathrm{TQ}$ Trentini CM. Qualidade de vida, cognição e desempenho nas funções executivas de idosos. Estud Psicol. 2012; 29(2):155-62.

4. Gonzaga JM, Barros SEB, Lisboa MGC; Barbieri FA, Gobbi LTB. Efeitos de diferentes tipos de exercício nos parâmetros do andar de idosas. Rev Bras Med Esporte. 2011; 17(3):166-70.

5. Elias RGM, Gonçalves ECA, Moraes ACF, Moreira CF, Fernandes CAMF. Aptidão física funcional de idosos praticantes de hidroginástica. Rev Bras Geriatr Gerontol. 2012; 15(1):79-86.

6. Carneiro DLF, Medalha J. Efeitos benéficos do treinamento de força em adolescentes. Rev Cient Integrada. 2013; 1(3):1-16.

7. Gobbi S, Villar R, Zago AS. Bases teórico-práticas do condicionamento físico. Rio de Janeiro: Guanabara Koogan; 2005. 
8. Oliveira RD, Pernambuco CS, Vale RGS, Dantaset EHM. Correlação entre autonomia funcional e qualidade de vida em idosas. Rev Bras Ciência Movim. 2009; 17(1):1-19.

9. Alberton CL, Rothmann CRC, Pinto SS, Coertjens M, Kruel LFM. Consumo de oxigênio e índice de esforço percebido em diferentes ritmos de execução na hidroginástica. Motriz. 2012; 18(3):423-31.

10. Soares PG. Motivos que levam à prática e à permanência na hidroginástica de pessoas na meia idade e idosos em Viçosa, MG. Efdportes. 2014; 18(189):1-15.

11. Prado RA. A influência dos exercícios resistidos no equilíbrio, mobilidade funcional e na qualidade de vida de idosas. Mundo Saúde. 2010; 34(2):183-91.

12. Instituto Brasileiro de Geografia e Estatística. Indicadores sócio demográficos prospectivos para o Brasil 1991-2030 [Internet]. 2012 [citado 2013 jan1]. Disponível em: http://www.ibge.gov.br/ home/estatistica/populacao/projecao

13. Folstein MF, Folstein SE, McHugh PR. Mini mental state: a practical method for grading the cognitive state of patients for clinician. J Psychiatr Res. 1975; 12(1):189-98.
14. Daniel FNR, Vale RGS, Giani TS, Bacellar S, Dantas EHM. Functional autonomy of elderly women enrolled in a physical activity program. Acta Sci Health Sci. 2012; 34(3):151-6.

15. Silva JGFB. Fortalecimiento muscular, nivel de fuerza muscular y autonomía funcional en una población de mujeres mayores. Rev Esp Ger Geront. 2009; 44(5):256-61.

16. Jerônimo DP, Souza FP, Silva LR, Teodoro PHS. Avaliação da autonomia funcional de idosas fisicamente ativas e sedentárias. Rev Bras Cienc Envelhec Hum. 2010; 8(2):173-8.

17. Miranda JE. Efeitos da Hidroginástica sobre o aumento da força de membros inferiores em idosas. Rev Bras Prescr Fisiol Exerc. 2014; 8(48):628-34.

18. Leite MT, Hildebrandt LM, Kirchner RM, Winck MT, Silva LAA, Franco GP. Cognitive and health conditions in elderly participants in recreation and leisure activities centers. Rev Gaúcha Enferm. 2012; 33(4):64-71.

19. Zortea B, Abreu DPG, Santos SSC, Silva BT, Ilha S, Cruz VD. Cognitive assessment on elderly people under ambulatory care. Rev Rene. 2015; 16(1):123-31. 